\title{
STRATEGI BERTAHAN HIDUP PEDAGANG ASONGAN DI STASIUN LEMPUYANGAN YOGYAKARTA DAN BALAPAN SOLO
}

\author{
Nur Hidayah $^{1}$
}

\begin{abstract}
Abstrak
Pembengkakan jumlah pekerja di sektor informal disebabkan terjadinya pertumbuhan ekonomi yang tidak seimbang antara pedesaan dan perkotaan, serta penggunaan teknologi padat modal telah menyebabkan lapangan kerja relatif lebih mahal dan melumpuhkan industri-industri yang berproduktivitas rendah. Pedagang asongan di stasiun Lempuyangan Yogyakarta dan stasiun Balapan Solo merupakah salah satu alternatif pekerjaan di sektor informal. Dimana dalam dimensi ketenagakerjaan, sektor informal mampu menampung tenaga kerja tanpa proses seleksi yang berbelit-belit, dan tidak membutuhkan modal yang besar besar serta keterampilan yang tinggi. Penelitian yang berjudul "Strategi Bertahan Hidup Pedagang Asongan di Stasiun Lempuyangan Yogyakarta dan Stasiun Balapan Solo": ini bertujuan untuk mengetahui strategi yang digunakan oleh para pedagang asongan dalam mempertahankan kelangsungan hidupnya.

Metode yang digunakan dalam penelitian ini adalah metode kualitatif yang menekankan pada aspek kedalaman informasi yang diperoleh melalui wawancara, didukung pula oleh observasi dan dokumentasi di lapangan. Informan yang diambil dalam penelitian ini sebanyak 5 orang yang terdiri dari 3 orang pedagang asongan di stasiun Lempuyangan Yogyakarta dan 2 orang pedagang asongan di stasiun Balapan Solo.

Hasil penelitian menunjukkan bahwa Pedagang asongan yang berjualan di sekitar stasiun Lempuyangan Yogyakarta dan stasiun Balapan Solo mempunyai strategi bertahan hidup yang bervariasi, diantaranya adalah dengan menjalankan kelangsungan perekonomian keluarga, diantaranya dengan pengelolaan keuangan keluarga dengan memprioritaskan kebutuhan yang penting serta mengelola agar pengeluaran tidak melebihi pemasukan, pendistribusian alokasi keuangan untuk pendidikan, makan sehari-hari dan lainnya, melalui pinjaman, ada pula dengan menabung. Kondisi ini ditemukan baik pada pedagang asongan di stasiun Lempuyangan Yogyakarta maupun di stasiun Balapan Solo. Apabila ditinjau lebih jauh lagi, kondisi ekonomi para pedagang asongan ini relative stagnan, hal ini ditunjukkan dengan lamanya mereka bekerja sebagai pedagang asongan, serta sedikitnya variasi strategi yang mereka jalankan untuk memenuhi kebutuhan hidup sehari-hari. Dalam hal ini mengindikasikan bahwa kurang adanya peningkatan yang signifikan pada kondisi perekonomian keluarga para pedagang asongan tersebut.
\end{abstract}

Kata kunci : strategi, pedagang asongan, stasiun

\footnotetext{
${ }^{1}$ Penulis adalah pengajar pada prodi Pendidikan Sosiologi FISE UNY
} 


\section{A. Pendahuluan}

Pembangunan manusia yang dicanangkan sebagai titik sentral pembangunan nasional bukanlah sematamata untuk mensukseskan pembangunan tetapi justru pembangunan itu sendiri harus ditujukan untuk manusia. Oleh karena sumber daya manusia bukan hanya sarana untuk memikul beban pembangunan, tetapi harus merupakan sasaran utama dari pembangunan. Ini berarti kesempatan kerja yang berhasil diciptakan oleh pembangunan merupakan salah satu tolok ukur dalam menilai keberhasilan pembangunan.

Pada waktu pemerintahan Orde Baru masih berkuasa, ekonomi merupakan anak emas mekanisme kebijakan pemerintah. Titik sentral pada faktor ekonomi didukung oleh perkembangan sektor formal dengan pengembangan berbagai industri di segala bidang. Proses sektor modern ini mendapatkan fasilitas yang komplit didukung birokrasi.

Namun timbul masalah pada saat industrialisasi memacu urbanisasi yang kemudian melahirkan problem ketenagakerjaan. Sektor formal yang tumbuh makin menguat tidak mampu menampung banyaknya tenaga kerja. Inilah yang menjadi awal lahirnya sektor informal yang kemudian menjadi alternatif pekerjaan masyarakat. Terlebih lagi ketika kondisi ekonomi Indonesia terpuruk dan diikuti jatuhnya berbagai industri sebagai pendukung sektor formal akibat kesalahan kebijakan. Banyak orang yang bekerja di sektor informal telah diberhentikan dan sebagian menjadi penganggur serta sebagian yang lain memilih banting stir bekerja di sektor informal.

Lapangan kerja di sektor informal bukan lapangan kerja sementara, tetapi merupakan pekerjaan yang relatif permanen dan stabil. Relatif banyaknya tenaga kerja kelompok umur produktif yang terlibat didalamya, relatif cukup lamanya mereka menekuni pekerjaan ini serta tidak menomorduakan atau mencadangkan lapangan kerja sektor informal dalam pilihan bekerja merupakan indikator yang dapat dijadikan tolok ukur bahwa lapangan kerja sektor informal bukanlah "media sementara" atau "batu loncatan” sebelum seseorang memperoleh pekerjaan di sektor formal.

Terjadinya pembengkakan jumlah pekerja di sektor informal disebabkan terjadinya pertumbuhan ekonomi yang tidak seimbang antara pedesaan dan perkotaan, serta penggunaan teknologi padat modal telah menyebabkan lapangan kerja relatif lebih mahal dan melumpuhkan industri-industri yang berproduktivitas rendah.

Pedagang asongan di stasiun Lempuyangan Yogyakarta dan stasiun Balapan Solo merupakah salah satu alternatif pekerjaan di sektor informal. Dimana dalam dimensi ketenagakerjaan, sektor informal mampu menampung tenaga kerja tanpa proses seleksi yang berbelitbelit, dan tidak membutuhkan modal yang besar besar serta keterampilan yang tinggi. Namun apakah hanya faktor ini yang menyebabkan mereka lebih memilih pekerjaan sebagai pedagang asongan di sektor informal dan bertahan untuk tetap menekuninya ? Lalu bagaimana pula strategi bertahan hidup mereka selama ini di tengah-tengah keadaan krisis ekonomi? Hal inilah salah satu yang ingin diungkap dalam penelitian ini di samping hal lain yang menarik untuk diteliti lebih lanjut.

\section{B. Kajian Pustaka}

\section{Strategi Bertahan Hidup}

Snel dan Staring dalam Resmi Setia (2005;6) mengemukakan bahwa strategi bertahan hidup adalah sebagai rangkaian tindakan yang dipilih secara standar oleh individu dan rumah tangga yang miskin secara sosial ekonomi. Melalui strategi ini seseorang bisa berusaha untuk menambah penghasilan lewat pemanfaatan sumbersumber lain ataupun mengurangi pengeluaran lewat pengurangan kuantitas dan kualitas barang atau jasa. Cara-cara individu menyusun strategi dipengaruhi oleh posisi individu atau kelompok dalam struktur masyarakat, sistem kepercayaan dan jaringan sosial yang dipilih, termasuk keahlian dalam memobilitasi sumber daya yang ada, tingkat keterampilan, kepemilikan aset, jenis pekerjaan, status gender dan motivasi pribadi. Nampak bahwa jaringan sosial dan kemampuan memobilisasi sumber daya yang ada termasuk didalamnya mendapatkan 
kepercayaan dari orang lain membantu individu dalam menyusun strategi bertahan hidup.

Dalam menyusun strategi, individu tidak hanya menjalankan satu jenis strategi saja, sehingga kemudian muncul istilah multiple survival strategies atau strategi bertahan jamak. Selanjutnya Snel dan Starring mengartikan hal ini sebagai kecenderungan pelaku-pelaku atau rumah tangga untuk memiliki pemasukan dari berbagai sumber daya yang berbeda, karena pemasukan tunggal terbukti tidak memadai untuk menyokong kebutuhan hidupnya. Strategi yang berbeda-beda ini dijalankan secara bersamaan dan akan saling membantu ketika ada strategi yang tidak bisa berjalan dengan baik.

\section{Teori Mc Clelland}

Dalam teori ini ditekankan mengenai adanya beberapa individu memiliki dorongan yang kuat untuk berhasil. Mereka lebih berjuang untuk memperoleh pencapaian pribadi daripada memperoleh penghargaan. Mereka memiliki keinginan untuk melakukan sesuatu dengan lebih baik atau efisien dibandingkan sebelumnya. Dorongan ini merupakan kebutuhan pencapaian (nAch). Mc Clelland dalam Robinson (2007:230) menemukan bahwa individu dengan prestasi tinggi membedakan diri mereka dari individu lain menurut keinginan mereka untuk melakukan hal-hal dengan lebih baik. Mereka mencari situasi-situasi dimana bisa mendapatkan tanggung jawab pribadi guna mencari solusi atas berbagai masalah, bisa menerima umpan balik yang cepat tentang kinerja sehingga dapat dengan mudah mereka berkembang atau tidak, dan dimana mereka bisa menentukan tujuan-tujuan yang cukup menantang.

Teori ini sesuai dengan fenomena yang terjadi pada aktivitas yang dilakukan oleh para pedagang asongan. Dengan kondisi ekonomi yang serba sulit, semangat kerja mereka tetap bertahan. yang telah termakan waktu tidak menurunkan semangat mereka untuk tetap bekerja. Keinginan untuk maju dan menginginkan hidup sejahtera bagi keluarga, menjadi alasan yang utama memilih profesi sebagai pedagang asongan.

\section{Teori Aksi}

Dalam teori ini ditekankan bahwa individu menentukan sendiri barang sesuatu yang bermakna bagi dirinya sendiri. Jadi sebagai subyek, manusia bertindak atau berperilaku untuk mencapai tujuan-tujuan tertentu yang memberikan makna baginya. Teori ini menjelaskan strategi untuk mempertahankan hidup khususnya pedagang Asongan di stasiun Lempuyangan Yogyakarta dan stasiun Balapan Solo.

Sesuai pandangan Hinkle diantara premis dari tujuh Teori Aksi disebutkan bahwa:

a. Sebagai subjek manusia bertindak atau berperilaku untuk mencapai tujuan-tujuan tertentu. Jadi tindakan manusia bukan tanpa tujuan.

b. Dalam bertindak manusia menggunakan cara, teknik, prosedur, metode serta perangkat yang diperkirakan cocok untuk mencapai tujuan tersebut.

Lain lagi menurut Parsons, teori aksi menggambarkan unit-unit dasar tindakan sosial dengan karakteristik sebagai berikut :

a. Adanya individu dengan aktor

b. Aktor dipandang sebagai pemburu tujuan-tujuan tertentu

c. Aktor mempunyai alternatif cara, alat serta teknik untuk mencapai tujuannya

d. Aktor berhadapan dengan sejumlah kondisi situasional yang dapat membatasi tindakannya dalam mencapai tujuan. Kendala tersebut berupa situasi dan kondisi, sebagian ada yang tidak dapat dikendalikan oleh individu

e. Aktor berada dibawah kendala dari nilai-nilai, norma-norma dan berbagai ide abstrak yang mempengaruhinya dalam memilih dan menentukan tujuan serta tindakan alternatif untuk mencapai tujuan.

\section{Hasil Penelitian dan Pembahasan}

\section{Deskripsi Wilayah Penelitian}

a. Stasiun Lempuyangan Yogyakarta

Lempuyangan tercatat sebagai salah satu stasiun yang dibangun pada masa awal pengembangan jaringan rel KA di wilayah tengah Pulau Jawa, sebelum secara de jure Pemerintah Hindia Belanda 
menyetujui undang-undang pembangunan jalan KA di pulau ini, sebuah perusahaan KA swasta telah lebih dulu beroperasi. NV Nederlandsch-Indische Spoorweg Maatschappij atau NISM telah membangun rel sepanjang 26 kilometer dengan rute Kemijen, Kota Semarang-Tanggung, Grobogan. Artinya, secara de facto NISM telah menghadirkan KA di Indonesia.

Jalur tersebut mulai dioperasikan 10 Agustus 1867. Setelah bisnisnya merugi, NISM meminta bantuan Pemerintah Hindia Belanda melanjutkan perluasan pembangunan rel sepanjang 166 kilometer menuju Yogyakarta. Stasiun Lempuyangan yang diresmikan 2 Maret 1872 menandai kehadiran KA pertama di wilayah ini yang melayani rute Yogyakarta-Semarang. Sekitar 15 tahun kemudian, tepatnya 2 Mei 1887, barulah hadir stasiun kedua di Yogyakarta, yaitu Tugu. Perkembangan jaringan rel dari Yogyakarta semakin luas setelah dibangun jalur Yogyakarta- Surakarta pada 1899. Tujuh tahun kemudian Stasiun Tugu melayani jalur dari Pegunungan Priangan hingga Surabaya. Setelah lebih kurang 135 tahun beroperasi, kini pengelolaan perkeretaapian di Yogyakarta dan sekitarnya menjadi tanggung jawab PT Kereta Api Daerah Operasi (Daop) VI Yogyakarta

\section{b. Stasiun Balapan Solo}

Lahan yang sekarang menjadi Stasiun Balapan dulunya merupakan AlunAlun Utara milik Keraton Mangkunegaran. Di dalam alun-alun itu terdapat lapangan pacuan kuda Balapan, yang berdiri sekitar tahun 1890, pada masa Mangkunegoro VII.

“Antara tahun 1890-1910, Solo sedang digalakkan terjadinya perubahan. Perubahan dari pola pedesaan menjadi pola perkotaan. Ide perubahan itu datang dari Pemerintah Kolonial Belanda. Hal ini dikemukakan oleh Drs. Soedarmono, SU, sejarahwan dari Universitas Sebelas Maret Surakarta. Ide perubahan ini pun direstui oleh dua kerajaan, Kasunanan dan Mangkunegaran.

Secara tidak langsung, ide-ide perubahan menuju pola perkotaan ini juga menyentuh soal sarana dan prasarana umum. Salah satunya menyangkut soal alat transportasi kereta api. Pemerintah
Kolonial Belanda sudah menggagas jalur rel kereta api dari Semarang (sebagai Ibu Kota Propinsi) menuju Solo, maka Solo harus punya stasiun kereta api. Lokasi lapangan pacuan kuda Balapan dianggap paling pas untuk menjadi sebuah stasiun, karena jalur rel bisa langsung mengarah ke Semarang. Akhirnya, pacuan kuda itu diubah menjadi sebuah stasiun, dan nama Balapan tetap dipertahankan.

Pada saat itu Stasiun Balapan dikelola oleh Staats Spoor (SS), dan sengaja dirancang sebagai stasiun antar kota dengan rel lebar. Lalu dikembangkan lagi jalur rel baru dari daerah-daerah di sekitar Solo menuju ke Stasiun Balapan. Jalur rel baru antar daerah ini dikelola oleh Nederland Indisch Spoor (NIS), lebar relnya sendiri lebih kecil dibanding rel milik SS, karena jalur rel NIS ini memang diperuntukkan bagi kereta berukuran kecil yang jarak tempuhnya tidak terlalu jauh.

Setelah Stasiun Balapan berdiri, stasiun-stasiun kecil juga mulai dibangun di dalam Kota Solo. Stasiun-stasiun tersebut berada di titik-titik strategis, yakni di Purwosari, Sriwedari, dan Jebres. Stasiun-stasiun itu dihubungkan oleh relrel yang melewati tengah kota. Berarti pada awal abad 20, Kota Solo sebenarnya sudah memiliki alat transportasi dalam kota berupa kereta. Salah satu buktinya adalah jalur rel yang ada di tepi jalan Slamet Riyadi, jalur rel ini masih digunakan hingga sekarang.

\section{Profil Informan}

Informan pada penelitian ini adalah para pedagang asongan yang berjualan di sekitar area stasiun Lempuyangan Yogyakarta dan stasiun Balapan Solo. Masing-masing pedagang mempunyai strategi sendiri-sendiri dalam mempertahankan kelangsungan hidup keluarga terutama pada roda perekonomiannya.

$$
\text { a.Ibu Kar }
$$

Ibu Kar berusia 65 tahun. Bekerja sebagai penjual nasi bungkus di sekitar stasiun Lempuyangan Yogyakarta. Beliau tinggal di Tegalrejo Yogyakarta. Suami beliau merupakan pensiunan PJKA. Ibu Kar mempunyai 6 anak. 
Awalnya beliau berjualan nasi bungkus sejak tahun 1980 di stasiun Tugu. Namun mulai tahun 1999, beliau pindah ke stasiun Lempuyangan. Setiap hari beliau berangkat dari rumah jam 06.00 pagi. Sementara untuk pulang ke rumah, waktunya tidak tentu karena tergantung habisnya dagangan. Ibu Kar mengungkapkan bahwa beliau memasak sendiri nasi gudeg dan lauknya. Setiap hari beliau membawa 11 bungkus, dengan satuan harga setiap bungkusnya Rp. 5000,-. Modal usaha tiap hari \pm Rp. 30.000,-. Kalau laku semua, maka mendapat uang Rp. 55.000,-. Dengan begitu beliau bisa kulakan lagi 10 bungkus seharga Rp. 15.000,-. Selama ini beliau mempunyai izin dagang, dengan memakai seragam hijau (model kebaya). Adapun kartu anggota asongan berwarna biru dikelola oleh PT. Kereta Api Persero Stasiun Besar Lempuyangan.

Untuk memenuhi kebutuhan sehari-hari ibu Kar mengandalkan dari hasil dagangannya. Selain itu beliau berusaha mengelola pengeluaran tidak melebihi pemasukan termasuk dalam pola makan diatur sedemikian rupa.

Pendistribusian alokasi, untuk pendidikan disendirikan, untuk kegiatan sosial dipisahkan, demikian untuk makan sehari-hari disendirikan. Beliau berusaha memprioritaskan jenis kebutuhan mana yang lebih didahulukan, sehingga yang benar-benar mendesak akan dipenuhi terlebih dahulu.

b. Ibu Pon

Seperti halnya ibu Kar, ibu Pon Berjualan nasi bungkus. Berjualan kurang lebih 20 tahun lamanya. Beliau berjualan mulai dari jam 6 pagi. Beliau mempunyai 3 anak. Pemasukan tidak seperti dulu, karena sekarang kereta eksekutif khusus beroperasi di stasiun Tugu. Sedangkan yang lain masih beroperasi di Lempuyangan. Dalam sehari Ibu Pon mendapatkan keuntungan + Rp. 20.000,- untuk dialokasikan pemenuhan kebutuhan sehari-hari. Bila kurang, beliau pun meminjam pada orang lain.

c. Ibu Sum

Ibu Sum berusia 42 tahun. Lahir pada tanggal 28 Januari 1967. Lulusan SMEA 3 Yogyakarta. Bekerja sebagai pedagang salak sejak tahun 2005.

Beliau mempunyai 2 anak, dimana salah satu anaknya bersekolah di SD Tegalrejo kelas 2 SD. Berangkat berjualan salak dari jam 5 pagi sampai jam 9 pagi di stasiun Lempuyangan. Sementara jam 10.00 - 14.00 beliau di rumah mengerjakan pekerjaan rumah tangga. Setelah itu meneruskan berjualan lagi di stasiun dari jam 14.00 - 17.00 WIB. Selama ini dagangan salaknya dikulak dari Pasar Kranggan. Setiap hari salak yang laku terjual ada $20-25 \mathrm{~kg}$.

Menurut ibu Sum, persaingan antar pedagang tidak ada. Baik dalam penjualan barang dan pembelinya harganya sama saja antar sesama pedagang. Bahkan lebih lanjut diungkapkannya bahwa aturan pedagang sudah sesuai.

Ibu Sum telah bercerai dari suaminya, sedangkan anak-anak ikut neneknya. Alokasi uang untuk keseharian digunakan untuk makan, sedangkan untuk memenuhi keperluan yang lain ia peroleh dengan cara meminjam.

Menurut ibu Sum, tidak ada persaingan dengan pedagang yang lain. Sementara modal yang ia punya cuma sedikit.

a. Ibu Suk

Ibu Suk berusia 65 tahun. Alamatnya di Kadipiro (pinggir rel kereta api). Suaminya yang bekerja sebagai tukang becak baru saja meninggal. Ibu Suk mempunyai 2 orang anak, yang satu ke Jakarta, sedang yang satu masih ikut ibu Suk. Bahkan beliau menanggung beban pada pembiayaan rumah tangga anaknya. 
Beliau tidak mempunyai modal sendiri, sehingga hanya mengambil untung dari hasil penjualan. Jenis dagangan yang ia jual adalah bakpia dan nasi bungkus.

Kalau dagangannya belum laku, maka beliau tidak mendapat uang. Maka jalan yang ditempuhnya dengan meminjam uang pada temannya untuk memenuhi kebutuhan sehari-hari. Setelah dagangannya laku, baru ia kembalikan pinjaman tersebut. Selama ini pendapatan belum tentu (tidak tentu).

b. Syt

Ibu Syt berusia 44 tahun. Beliau mempunyai etalase, dengan membayar pajak Rp. 30.000,- tiap bulan. Beliau berjualan sejak tahun 1981, awalnya beliau hanya membantu ibunya berjualan. Jenis dagangan yang dijual adalah makanan dan minuman. Pemasukan per hari bila ramai mencapai Rp. 50.000,-. Bila sepi, pemasukannya hanya mencapai Rp. 20.000,-.

Adapun suami ibu Syt saat ini bekerja di PJKA, sedangkan anak mereka satu orang dan masih sekolah. Kalau ada pemasukan lebih, ditabung.

Dengan demikian, masing-masing informan mempunyai strategi dalam menjalankan kelangsungan perekonomian keluarga, diantaranya dengan pengelolaan keuangan keluarga dengan memprioritaskan kebutuhan yang penting serta mengelola agar pengeluaran tidak melebihi pemasukan, pendistribusian alokasi keuangan untuk pendidikan, makan sehari-hari dan lainnya, melalui pinjaman, ada pula dengan menabung.

\section{Strategi Bertahan Hidup Pedagang Asongan di Stasiun Lempuyangan Yogyakarta dan Balapan Solo}

Strategi bertahan hidup pedagang asongan di stasiun Lempuyangan dan Balapan Soslo dalam menjalankan kelangsungan perekonomian keluarga dapat dijelaskan sebagai berikut :

a. Adanya skala prioritas kebutuhan yang penting serta mengelola agar pengeluaran tidak melebihi pemasukan. Hal ini merupakan bagian dari manajemen keluarga yang diterapkan oleh pedagang asongan.

b. Adanya pendistribusian alokasi keuangan untuk pendidikan, makan sehari-hari dan lainnya. Dalam hal ini sudah ada alokasi yang jelas untuk memenuhi kebutuhan pendidikan bagi anak-anak, keperluan belanja untuk memenuhi kebutuhan makan sehari-hari, pemenuhan kebutuhan pembayaran fasilitas listrik, acara tak terduga seperti sumbangan bila tetangga hajatan.

c. Meminjam (berhutang) pada teman, tetangga dan lainnya. Kondisi para pedagang asongan.

d. Menabung. Sebagian penghasilan dari berdagang asongan ditabung untuk keperluan pendidikan anak dan lain-lain. Bahkan terkadang untuk keperluan tak terduga.

e. Mengganti jenis dagangan sesuai dengan periode musim buahbuahan. Hal ini berlaku pada pedagang asongan yang berjualan buah-buahan. Sehingga ketika musim buah salak maka pedagang asongan akan menjual salak, demikian pula ketika musim buah mangga maka pedagang tersebut akan menjual mangga. Begitu seterusnya hampir di setiap periode pergantian musim buah berlaku demikian.

Ada hal menarik yang perlu dikaji lebih jauh yaitu kondisi ekonomi para pedagang asongan ini relatif stagnan, hal ini ditunjukkan dengan lamanya mereka bekerja sebagai pedagang asongan, serta minimnya variasi strategi yang mereka jalankan untuk memenuhi kebutuhan hidup sehari-hari. Dalam hal ini mengindikasikan bahwa kurang adanya peningkatan yang signifikan pada kondisi perekonomian keluarga para pedagang asongan tersebut.

\section{Kesimpulan dan Saran \\ 1. Kesimpulan}

Pedagang asongan yang berjualan di sekitar stasiun Lempuyangan Yogyakarta dan stasiun Balapan Solo mempunyai strategi bertahan hidup yang bervariasi, 
diantaranya adalah dengan menjalankan kelangsungan perekonomian keluarga, diantaranya dengan pengelolaan keuangan keluarga dengan memprioritaskan kebutuhan yang penting serta mengelola agar pengeluaran tidak melebihi pemasukan, pendistribusian alokasi keuangan untuk pendidikan, makan seharihari dan lainnya, melalui pinjaman, ada pula dengan menabung. Kondisi ini ditemukan baik pada pedagang asongan di stasiun Lempuyangan Yogyakarta maupun di stasiun Balapan Solo.

Apabila ditinjau lebih jauh lagi, kondisi ekonomi para pedagang asongan ini relative stagnan, hal ini ditunjukkan dengan lamanya mereka bekerja sebagai pedagang asongan, serta sedikitnya variasi strategi yang mereka jalankan untuk memenuhi kebutuhan hidup sehari-hari. Dalam hal ini mengindikasikan bahwa kurang adanya peningkatan yang signifikan pada kondisi perekonomian keluarga para pedagang asongan tersebut.

\section{Saran}

Setelah melakukan penelitian tentang strategi bertahan hidup pedagang asongan di stasiun Lempuyangan Yogyakarta dan Balapan Solo, maka ada beberapa saran yang diajukan yaitu :

a. Bagi pedagang asongan

Para pedagang asongan hendaknya memperhatikan kondisi fisik yang prima dalam berdagang serta berupaya menggunakan variasi strategi lain yang bisa menopang kehidupan perekonomian keluarga mereka.

b. Bagi Masyarakat Seyogyanya

menghargai pekerjaan para pedagang asongan yang dengan gigihnya terus berdagang untuk memenuhi kebutuhan perekonomian keluarganya.

c. Pengelola stasiun Lempuyangan Yogyakarta dan Balapan Solo Seyogyanya semakin meningkatkan perhatiannya pada para pedagang asongan yang berjualan di sekitar area stasiun. Mengingat di stasiun Lempunyangan sudah terkoordinasi dengan baik paguyuban antar pedagang asongan, serta adanya Kartu Asongan yang diberikan oleh pengelola stasiun menunjukkan pembinaan serius terhadap para pedagang asongan. Hal ini perlu ditiru pula oleh pengelola stasiun Balapan Solo.

\section{Daftar Pustaka}

Moleong, Lexy J. (1998). Metode

Penelitian Kualitatif. Cetakan ke-9.

Bandung : Rosda Karya.

Soekanto, Soerjono. (2005). Sosiologi

Suatu Pengantar. Cetakan ke-38.Jakarta: PT RadjaGrafindo Persada.

Robbins, Sthephen and Timothy A. Judge. (2007). Perilaku Organisasi. Jakarta;

Salemba Empat

Hidayat. (1986). "Wanita dan Sektor Informal : Potensi dan Masalah”. Paper Lokakarya Dinamika Wanita yang Berusaha di Sektor Informal”. Tidak diterbitkan.

Resmi Setia. (2005). Gali Tutup Lubang Itu Biasa : Strategi Buruh Menanggulangi Persoalan dari Waktu ke Waktu. Bandung : Yayasan Akatiga 